\title{
IDENTIFIKASI KAPANG PADA RUMPUT LAUT Eucheuma cottonii (Kappaphycus alvarezii) KERING DARI DESA RAP RAP ARAKAN KECAMATAN TATAPAAN KABUPATEN MINAHASA SELATAN
}

\author{
Andreas Teurupun, Semuel M Timbowo dan Joyce CV Palenewen
}

Fakultas Perikanan dan Ilmu Kelautan, Universitas Sam Ratulangi, Manado, Sulawesi Utara.

\begin{abstract}
ABSTRAK
Rumput laut merupakan salah satu sumber devisa negara dan sumber pendapatan bagi masyarakat pesisir dan merupakan salah satu komoditi laut yang sangat populer dalam perdagangan dunia, karena pemanfaatannya yang demikian luas dalam kehidupan sehari-hari, baik sebagai sumber pangan, obat-obatan dan bahan baku industri. Rumput laut akan bernilai ekonomis setelah mendapat penanganan lebih lanjut. Umumnya penanganan pasca panen rumput laut oleh petani hanya sampai pada tahap pengeringan. Prinsip pengeringan adalah suatu cara untuk mengeluarkan atau menghilangkan sebagian air yang terkandung melalui penggunaan energi panas. Penelitian ini bertujuan untuk mengidentifikasi jenis kapang dan menghitung total jamur yang terdapat pada rumput laut Eucheuma cottonii (Kappaphycus alvarezii) kering yang diambil dari Desa Rap-Rap Arakan Kecamatan Tatapaan, Kabupaten Minahasa Selatan. Penelitian ini dilakukan di laboratorium dengan parameter yang diuji meliputi parameter mikrobiologi: total kapang, identifikasi kapang dan parameter kimia: kadar air dan nilai $\mathrm{pH}$. Metode yang digunakan dalam penelitian ini adalah metode eksploratif yaitu suatu metode penelitian yang dilakukan untuk mengungkapkan keterangan dari suatu fakta tertentu secara terperinci dan sistematik. Hasil penelitian menunjukkan bahwa kisaran total koloni kapang tertinggi adalah pada pengambilan pertama yaitu $3,0 \times 10^{3}$ dan yang terendah adalah pada pengambilan kedua yaitu $2,0 \times 10^{3}$. Kadar air tertinggi pada pengambilan kedua yaitu $6,68 \%$ dan terendah pada pengambilan pertama yaitu $6,55 \%$. Sedangkan nilai $\mathrm{pH}$ tertinggi 5,58 (pengambilan pertama) dan terendah 5,23 (pengambilan kedua). Berdasarkan hasil parameter tersebut, jenis kapang yang teridentifikasi pada rumput laut $K$. Alvarezii adalah Fusarium sp dan Penicillium sp.
\end{abstract}

Kata kunci: rumput laut, kapang, Eucheuma cottonii.

\section{PENDAHULUAN}

Rumput laut merupakan salah satu sumber devisa negara dan sumber pendapatan bagi masyarakat pesisir dan merupakan salah satu komoditi laut yang sangat populer dalam perdagangan dunia, karena pemanfaatannya yang demikian luas dalam kehidupan seharihari, baik sebagai sumber pangan, obat-obatan dan bahan baku industri (Indriani dan Sumiarsih, 1991).

Rumput laut masih banyak diekspor dalam bentuk bahan mentah yaitu berupa rumput laut kering. Rumput laut yang ada di perairan Indonesia tidak semua bermanfaat bagi manusia. Rumput laut yang banyak dimanfaatkan adalah dari jenis ganggang merah dan ganggang cokelat karena mengandung agaragar, karaginan, porpiran, dan furcelaran. Menurut Anam dkk., 2010. Sebanyak 70\% produksi bahan mentah rumput laut kering di ekspor ke China, Uni Eropa, dan Filipina. Pasar dalam negeri masih menyerap $30 \%$ bahan mentah rumput laut kering.

Rumput laut akan bernilai ekonomis setelah mendapat penanganan lebih lanjut. Umumnya penanganan pasca panen rumput laut oleh petani hanya sampai pada tahap pengeringan (Indriani dan Sumiarsih, 1991). Prinsip pengeringan adalah suatu cara untuk mengeluarkan atau menghilangkan sebagian air yang terkandung melalui penggunaan energi panas. Biasanya, kandungan air bahan tersebut dikurangi sampai batas terkecil sehingga mikro organisme tidak dapat tumbuh lagi di dalamnya tergantung dari jenis bahan yang dikeringkan (Winarno, 1992).

Kerusakan pada produk olahan dapat disebabkan oleh kerusakan fisik, mekanis, kimia dan mikrobiologis. Kerusakan secara mikrobiologis merupakan bentuk kerusakan yang sangat merugikan terhadap hasil perikanan serta dapat menimbulkan penyakit bagi kesehatan manusia karena dapat memproduksi racun dan salah satu penyebab adalah oleh 
mikro organisme yaitu kapang. Kapang dalam pertumbuhannya dapat memproduksi zat kimia yang bersifat racun yang disebut mikotoksin (Hall, 1970).

Sehubungan dengan hal di atas maka penulis mengadakan penelitian untuk identifikasi beberapa jenis kapang yang tumbuh pada rumput laut (Kappaphycus alvarezii) kering yang diambil dari Desa Rap-Rap Arakan Kecamatan Tatapaan, Kabupaten Minahasa Selatan, Provinsi Sulawesi Utara. Tujuan penelitian ini adalah untuk mengidentifikasi jenis kapang dan menghitung total jamur yang terdapat pada rumput laut Eucheuma cottonii (K. alvarezii) kering.

\section{METODOLOGI PENELITIAN}

\section{Alat dan Bahan}

Alat yang digunakan terdiri atas autoclaf, cawan petri, panci stainless tell, pengaduk, blender, inkubator, timbangan analitik, tabung reaksi, oven, pipet, lampu spritus, erlenmeyer, mikroskop, desikator, alumunium foil, magnetic stirrer dan $\mathrm{pH}$ meter, spatula, gelas ukur, cawan porselin, kertas pembungkus. Bahan untuk penelitian ini terdiri atas: rumput laut, $\mathrm{NaCl}$, Akuades, Potato Dextrose Agar, Vaselin, Alkohol dan Silikagel.

\section{Tata Laksana Penelitian}

Sampel rumput laut E. cottonii (K. alvarezii) segar diambil dari Desa Rap-rap sebanyak $6 \mathrm{~kg}$. Sampel diambil langsung dari laut dengan menggunakan perahu katinting. Sebanyak $3 \mathrm{~kg}$ sampel rumput laut $K$. alvarezii diambil untuk pengambilan pertama dan $3 \mathrm{~kg}$ lagi untuk pengambilan kedua. Sampel yang sudah ditimbang, langsung dimasukkan ke dalam cool box untuk kemudian dibawa ke laboratorium. Jarak yang ditempuh dari lokasi pengambilan sampel sampai ke laboratorium adalah $\pm 35-40 \mathrm{~km}$ dengan waktu tempuh \pm 1 jam.

Setelah sampai di laboratorium, sampel dicuci terlebih dahulu kemudian dikeringkan dengan cara diangin-anginkan selama 3 hari. Proses pengeringan dilakukan dengan cara sampel digantung menggunakan tali rafia yang digantung dalam ruangan dengan berat basah 1,5 kg. Setelah 3 hari diangin-anginkan, kemudian dimasukkan ke dalam oven dengan suhu $40^{\circ}-50^{\circ} \mathrm{C}$ selama 3 hari dengan berat $141,84 \mathrm{~g}$.
Setelah itu diblender dengan tujuan menghomogenkan sampel. Sampel yang telah diblender, kemudian dipisahkan untuk pengujian yaitu: total koloni kapang sebanyak $10 \mathrm{~g}$, uji pH sebanyak $10 \mathrm{~g}$ sedangkan uji kadar air sebanyak $3 \mathrm{~g}$.

\section{HASIL DAN PEMBAHASAN}

\section{Total koloni kapang}

Hasil perhitungan koloni kapang pada rumput laut kering yang diinkubasi selama 7 hari dengan menggunakan suhu inkubasi $30^{\circ} \mathrm{C}$ selama 3, 5 dan 7 hari dapat dilihat pada Tabel 1. Data jumlah koloni kapang pada sampel rumput laut kering.

Dari data yang diperoleh, hasil perhitungan total koloni kapang berdasarkan data, menunjukkan bahwa nilai kapang berkisar antara 2,0 × $10^{3}-3,0 \times 10^{3} \mathrm{CFU} /$ gram (Tabel 2). Tabel 3, menunjukkan bahwa total koloni kapang tertinggi yaitu 3,0 x $10^{3} \mathrm{CFU} / \mathrm{gram}$.

Tabel 1. Jumlah koloni kapang pada rumput laut.

\begin{tabular}{ccccc}
\hline \multirow{2}{*}{ Kode Sampel } & \multirow{2}{*}{ Waktu } & \multicolumn{3}{c}{ Pengenceran } \\
\cline { 3 - 5 } & \multirow{2}{*}{ A1 hari } & 4 & 1 & 0 \\
& \multirow{3}{*}{5 hari } & 3 & 1 & 0 \\
& \multirow{3}{*}{7 hari } & 2 & 3 & 0 \\
& & 1 & 0 & 0 \\
& & 0 & 1 & 0 \\
\hline A2 3 hari & 5 & 0 & 1 \\
& \multirow{3}{*}{5 hari } & 8 & 1 & 0 \\
& & 7 & 1 & 1 \\
& \multirow{3}{*}{7 hari } & 5 & 0 & 0 \\
& & 5 & 1 & 1 \\
& & 6 & 0 & 0 \\
\hline
\end{tabular}

Ket.: A1 (pengambilan pertama); A2 (pengambilan kedua)

Tabel 2. Kisaran total koloni kapang pada rumput laut kering.

\begin{tabular}{ccc} 
SAMPEL & SAMPLING & $\begin{array}{c}\text { Kisaran Total Koloni } \\
\text { Kapang CFU/gram }\end{array}$ \\
\hline E. Cottonii & 1 & $7,0 \times 10^{-2}$ \\
& 2 & $4,0 \times 10^{-2}$ \\
\hline
\end{tabular}

Tabel 3. Hasil identifikasi kapang.

\begin{tabular}{cc}
\hline Sampel & Jenis Kapang \\
\hline A1 & Fusarium $\mathrm{sp}$. \\
& Penicillium $\mathrm{sp}$. \\
$\mathrm{A} 2$ & Fusarium $\mathrm{sp}$. \\
\hline
\end{tabular}

Ket: A1 (pengambilan pertama); A2 (pengambilan kedua)

\section{Identifikasi Kapang}

Dari hasil pengamatan pada media PDA dapat dilihat penampakkan kapang berserabut seperti kapas atau benang-benang (Gambar 1). Gambar ini terlihat pertumbuhan kapang berwarna putih seperti kapas yang diduga 
adalah Fusarium, dan berwarna krem diduga Penicillium. Hal ini juga dipertegas oleh Pisalemo (2011) bahwa kapang yang berwarna putih seperti kapas merupakan Fusarium sp.

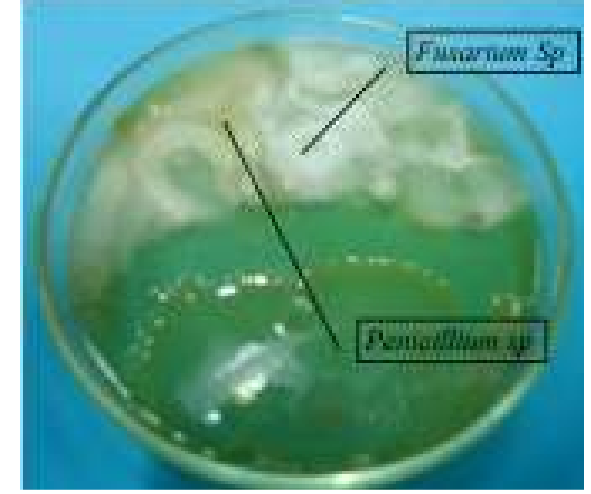

Gambar 1. Pertumbuhan kapang pada media PDA hari ke 7

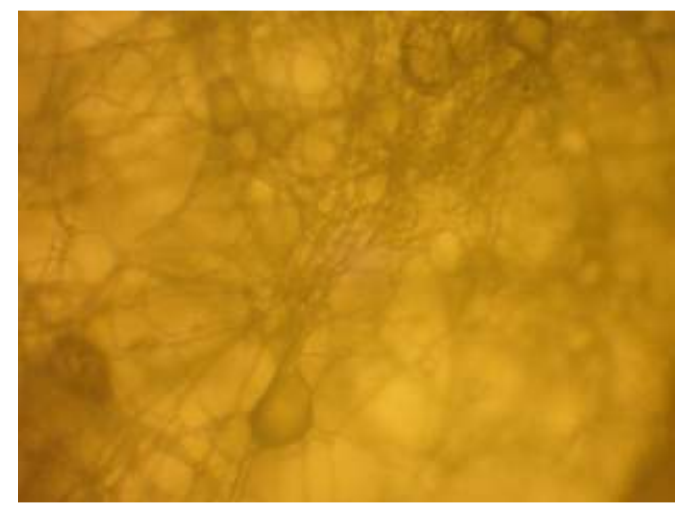

Gambar 2. Bentuk Fusarium sp. pada rumput laut kering.

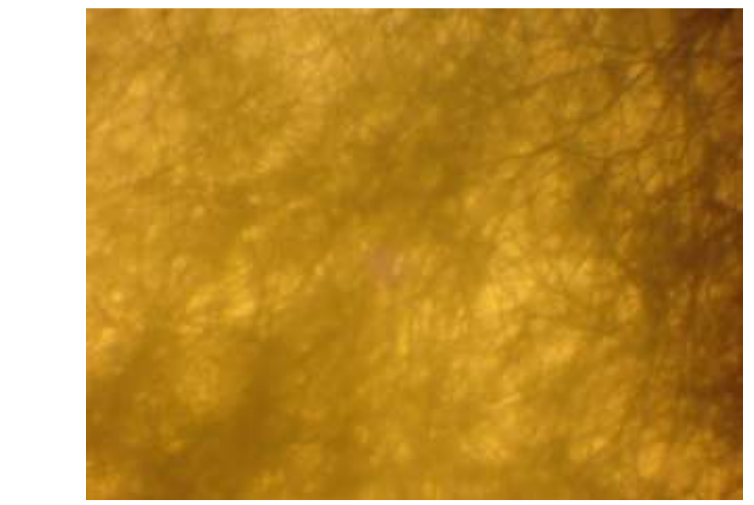

Gambar 3. Penicillium sp pada rumput laut kering.

Untuk menentukan jenis kapang yang tumbuh dilakukan pengamatan di bawah mikroskop dengan pembesaran 640x dan membandingkan dengan struktur morfologi menurut Cappuccino dan Sherman (1992). Kemudian dilakukan pemotretan dengan menggunakan kamera Sony W320. Dari hasil pengamatan dengan menggunakan mikroskop dan membandingkan dengan struktur morfologi menurut Cappuccino dan Sherman (1992), maka kapang yang teridentifikasi dari rumput laut kering yaitu Fusarium sp. dan Penicillium sp.

\section{Fusarium sp.}

Fusarium sp. merupakan salah satu dari beberapa genera yang menghasilkan mikotoksin (Sudarmadji, 1989). Menurut Fardiaz (1992), Fusarium sp. tumbuh pada bahan pangan dan sulit diidentifikasi karena penampakkan pertumbuhannya bervariasi. Fusarium sp yang diamati dengan mikroskop pada rumput laut dapat dilihat pada Gambar 2.

\section{Penicillium sp.}

Menurut Dwijoseputro (1981) bahwa genus Penicillium meliputi genera yang membentuk konidia dengan satu struktur yang disebut Penicillius (sapu kecil). Bentuk Penicillium sp. yang diamati menggunakan mikroskop pada rumput laut kering dapat dilihat pada Gambar 3.

\section{Kadar Air}

Nilai kadar air tertinggi pada sampel pengambilan kedua yaitu $6,68 \%$ sedangkan yang terendah pada sampel pengambilan pertama 6,55\%. Menurut Fardiaz (1992) bahwa kapang dapat tumbuh pada kadar air yang rendah, karena kapang merupakan mikro organisme yang memerlukan air untuk pertumbuhannya. Kandungan air dalam bahan pangan mempengaruhi daya tahan bahan pangan tersebut terhadap pertumbuhan mikroba. pertumbuhan mikroba tidak pernah terjadi tanpa adanya air. selanjutnya menurut Benwart, (1989) bahwa Penicillium sp. dapat tumbuh pada kadar air lebih besar 22\%. Untuk Fusarium sp. dapat tumbuh pada kadar air 24\% atau lebih besar (Makfoeld, 1993).

Tabel 4. Nilai kisaran kadar air pada rumput laut.

\begin{tabular}{ccc}
\hline Sampel & Sampling & Kadar air (\%) \\
\hline A & 1 & $6,55 \%$ \\
A & 2 & $6,68 \%$ \\
\hline
\end{tabular}

Tabel 5. Nilai kisaran pH pada rumput laut

\begin{tabular}{ccc}
\hline Sampel & Sampling & Nilai $\mathbf{~ p H}$ \\
\hline A & 1 & 5,58 \\
A & 2 & 5,23 \\
\hline
\end{tabular}

\section{Nilai pH}

Tabel 5 menunjukkan bahwa nilai $\mathrm{pH}$ tertinggi yaitu 5,58 yang merupakan sampel pengambilan pertama, sedangkan nilai $\mathrm{pH}$ terendah yaitu 5,23 yang merupakan sampel 
pengambilan kedua. Berdasarkan hasil uji $\mathrm{pH}$ ini dihubungkan dengan pertumbuhan Penicillium sp. dan Fusarium sp., kedua kapang ini tumbuh pada kisaran $\mathrm{pH}$ tersebut. Hal ini dipertegas oleh Fardiaz (1992) bahwa kapang tumbuh pada kisaran $\mathrm{pH}$ yaitu $2,0-8,5$ tetapi biasanya pertumbuhan kapang akan lebih baik pada kondisi $\mathrm{pH}$ rendah. Penicillium sp. dapat tumbuh pada $\mathrm{pH}$ 1,9-9,3 dengan $\mathrm{pH}$ optimum 6-7 (Benwart, 1989). Untuk Fusarium sp. dapat tumbuh pada pH 2,0-8,5 (Makfoeld, 1993).

\section{KESIMPULAN DAN SARAN}

\section{Kesimpulan}

Kapang yang teridentifikasi pada rumput laut Eucheuma cottonii (Kappaphycus alvarezii) kering yang diambil dari Desa Rap rap Arakan Kecamatan Tatapaan Kabupaten Minahasa Selatan yaitu: Fusarium sp. dan Penicillium sp. dengan jumlah total koloni kapang tertinggi yaitu $7,0 \times 10^{-2} \mathrm{CFU} /$ gram, kadar air tertinggi yaitu $6,68 \%$, dan nilai $\mathrm{pH}$ tertinggi yaitu 5,58.

\section{Saran}

Perlu diadakan penelitian lanjut tentang spesies kapang yang terdapat pada rumput laut Eucheuma cottonii (Kappaphycus alvarezii) kering.

\section{DAFTAR PUSTAKA}

Anam Khairul, Damayanti Dini, Supratman Lilis, Sianturi DRM. 2010. Laporan Logical Framework Approach (LFA). Pengembangan Usaha Budidaya Rumput Laut di Kepulauan Seribu, Provinsi DKI Jakarta. Departemen Pendidikan Nasional SPS Institut Pertanian Bogor Program Multi Disiplin Mayor Bioteknologi Bogor 2010.

Banwart, GJ. 1989. Basic Food Microbiology. Second Edition. Chapman and hall. New York.

Cappuccino, JG Sherman Natalie. 1992. Microbiology a Laboratory Manual. Third Edition. The Benjamin. New York.

Dwijoseputro, D. 1981. Dasar-dasar Mikrobiologi. Djambatan. Jakarta.

Fardiaz, S. 1992 Mikrobiologi Pangan 1. Jurusan Teknologi Pangan dan Gizi. IPB Bogor.

Hall, DW. 1970. Handling and Storage Of Food Grains In Tropical and Subtropical Area. Roma.

Indriani H, Sumiarsih E. 1991. Rumput Laut. Penebar Swadaya. Jakarta. $99 \mathrm{hlm}$.

Makfoeld, Dj. 1993. Mikotoksin Pangan. Kanisius. Yokyakarta.

Pisalemo, BE. 2011. Kapang Pada Ikan Pisang-Pisang (Caesio chrysozonus) Asin dari Pasar Pinasungkulan Dan Bersehati Manado. Skripsi. Fakultas Perikanan Dan Ilmu Kelautan. Unsrat. Manado.

Winarno. 1992. Pangan Gizi, Teknologi dan Konsumen. PT Gramedia Pustaka Utama. Jakarta. 